\title{
MAJLIS TA'LIM (ISLAMIC FORUM) AND HARMONIZING INTER FAITH COMMUNICATION
}

\author{
Zaenal Abidin \\ Universitas Muhammadiyah Surakarta, Indonesia \\ Email: zenith.26112010@gmail.com
}

\begin{abstract}
The process of growing multiculturalism and tolerance values among religious followers to the community in Indonesia can be done through religious lectures in majlis ta'lim (Islamic forum) in mosques, houses, meeting halls, etc. The lectures delivered were concerned about democracy, justice and law, cultural values and ethos, equality in differences, ethnicity, religious beliefs, cultural expressions, private and public domains, human rights, community cultural rights, and other relevant concepts. In this case, majlis ta'lim (Islamic forum) can be seen as a solution of growing the seeds of democracy, tolerance and multiculturalism for the harmonization among religious groups Indonesia. Majlis Ta'lim (Islamic forum) is a great potential since it can create a harmonious and free from radical values country, and able to reduce issues of SARA (ethnicity, religion, ancestry, and group of people), which are often raised from the institutionalization of community. Good understanding of democracy, tolerance and multiculturalism are aligned with the Islamic values.
\end{abstract}

Keywords: Multiculturalism, Democracy, Tolerance, SARA, Majlis Taklim.

\begin{abstract}
Abstrak
Proses penanaman nilai-nilai multikulturalisme dan toleransi antar umat beragama kepada masyarakat di Indonesia bisa dilakukan dengan ceramah/pengajian di majlis taklim yang tersebar di masjid, musholla, perumahan, ruang/balai pertemuan dan lain sebagainya. Materi ceramah yang disampaikan adalah berkaitan dengan masalah demokrasi, keadilan dan hukum, nilai-nilai budaya dan etos, kebersamaan dalam perbedaan yang sederajat, suku bangsa, kesukubangsaan, kebudayaan sukubangsa, keyakinan keagamaan, ungkapan-ungkapan budaya, domain privat dan publik, hak asasi manusia, hak budaya komunitas, dan tentang konsep-konsep lainnya yang relevan. Dalam hal ini maka majlis taklim dapat dipandang sebagai sebuah solusi untuk dijadikan sebuah lahan penanaman bibit-bibit demokrasi, toleransi dan multicultural demi mekarnya keharmonisan antar umat beragama di Negara Republik Indonesia ini.Karena majlis taklim juga merupakan potensi besar yang dimiliki oleh Negara ini untuk dapat mensukseskan terciptanya Negara yang harmonis dan terbebas dari paham radikal serta mampu meredam konflik-konflik yang ditimbulkan dari efek SARA, yang sering kali dimunculkan dari adanya Institusionalisasi suatu komunitas.Dengan pemahaman yang baik atas demokrasi, toleransi dan multicultural yang sejalan dengan ajaran agama Islam.
\end{abstract}

Kata kunci: Multikulturalisme, Demokrasi, Toleransi, SARA, Majlis Taklim. 


\section{INTRODUCTION}

Indonesia is a wealthy archipelago country, which its diversity of cultures, races, ethnicities, beliefs, religions, vernacular languages, etc. Although it is full of cultural diversity, Indonesia is "one" with its slogan, Bhineka Tunggal Ika which means "Unity in diveristy". Cultural diversity is supported by the territory of the Indonesia which is separated by the sea. As a country consisting of diverse cultures, religions, groups, tribes and customs, the diversity can be a challenge and a potency for this nation. Inter-cultural contacts provide opportunities of conflict if there is no mutual understanding and respect in society (Tilaar, 2004: 9-10).

Cultural diversity has a dual dimension. The positive side, it can strengthen the unity, while the negative side it can cause chaos. In society, many characters of individualism and selfishness arise, whether in the name of religion, belief, class, ethnicity, or politics. These traits can change into exclusivism and finally lead into chaos, especially if the poor economic state, social and cultural problems were augmented (Syammsudin, 2016, p. 1-12)

Conflicts that have occurred in Indonesia give a signal that some people are unable to accept differences in social, political, economic and religious life. Internal religious conflicts also occured in Nangkernang, Karang Gayam Village, Omben District, Sampang Regency, Madura, East Java. The attack occurred in 2012 which caused the death of two Syi'ah followers, six were seriously injured, and dozens more were injured. This conflict has actually been going on for a long time, since 2004. The climax was the burning of the house of the Al-Bait Ahl Jamaat Association (IJABI) leader and two houses of Syi'ah followers and a mosque. This act was done by around 500 people who claim as the followers of Ahlus Sunnah Wal-Jamaah (Yunus, 2014, p. 223).

The "homogenization" of Indonesian Islam led by the conservative Sunni groups which was seen in the Syi'ah case in Yogyakarta called 
Rausyan Fikir was attacked by radical groups FJI (Front Islamic Jihad) in November and December 2013. Almakin stated that the terror scenario against Rausyan was not a stand-alone event, but a part of major movements for the homogenization of Indonesian Islam. This anti-Syi'ah propaganda was designed and supported by national and local level actors: local radical groups acted as executors of attacks, while nationallevel conservative activists spread anti-Syi'ah propaganda (Makin, 2017: $1-2)$.

The intolerance and anti-multiculturalism treatment was also experienced by the Muhammadiyah Association when the Lecture Hall and the pillar of the At-Taqwa Muhammadiyah Mosque construction were burned by a group of people in Sangso Village, Samalanga District, Bireuen District, Tuesday (10/17) at around 20.00 WIB. The arson was allegedly done by the perpetrators because they considered Muhammadiyah as wahabi (republika.co.id). Likewise, Ittihadul Ma'ahid Muhammadiyah (ITMAM/ Muhammadiyah Islamic Boarding School Association) when they were about holding a Daurah Tahfidzul Qur'an, a two-month memorizing 30 chapter of Al-Qur'an program, in Karimunjawa Jepara also got threatened to be dissoluted by intolerant groups. The reason is that the building they used has no Building Construction Licence (sangpencerah.id).

Social conflicts also occured in Bantul between the Tafsir Alquran Forum (MTA) and Nahdlatul Ulama Forum. The internal religious conflicts between Tafsir Al-Qur'an Forum and Nahdlatul Ulama Forum that occur in Bantul Regency were caused by theological differences. Secondly, horizontal conflicts that occur between Tafsir Al-Qur'an Forum and Nahdlatul Ulama Forum are not motivated by political factors. Thirdly, despite displaying a radical pattern, Tafsir Al-Qur'an Forum has succeeded in inviting some syncretic communities from puritanengan muslim to join as Tafsir Al-Qur'an Forum members (Afida, 2014). 
Nur Setiawati (2012: 81-95) states that the existence of the current islamic forum has widely gained a spot and role in society. Islamic forum as a form of islamic preaching organization is also referred as the center of Islamic learning (Islamic learning institution). As a center of Islamic learning, islamic forum are known to have contributed a huge role in educating the community, especially in religious learning and strengthening moral values.

\section{HARMONIZING INTER FAITH SOCIETY}

To achieve a harmony of inter faith society in Indonesia, at least every citizen, especially Muslims, must understand the following:

\section{Democracy}

Indonesia is considered as a country which can build democracy, strengthening civil society and upholding human rights through the basis of the Pancasila. Bakri gives support to Pancasila when explaining the meaning of ulu al-amr in Surah an-Nisa' [4] verse 83. The meaning of ulu al-amr in that verse is a democratic government, in Indonesian context, it is Pancasila democracy (Syahid, 1979, p. 153). He gave similar support when describing the meaning of Surah Yunus [10] verse 7 by stating that the hope of Indonesia is Believe in the One Supreme God, not an atheist, secular, and/or Islamic country (Shahid, 1979, p. 364). As for Dawam and Syu'bah, they generally asserted that democracy as an Islamic matter and Pancasila is one of the reason that links the values of democracy and Islam. Jakarta Charter, which has Pancasila in it, as for Dawam, is kalimatun sawa' which is supported by Islamic values.

Zamroni (2007, p. 31-32) states that the main idea of democracy is a view of life, which is reflected by the need of participation from every mature citizen in shaping the life values. He also stated that democracy would grow steadily if the cultural and democratic values were growing in the community, called: tolerance, the right of giving and respecting 
different opinion, understanding diversity in society, being open in communication, upholding the values and dignity of humanity, selfconfidence or independent, mutual respect, self control, togetherness, and stability.

The social pathologies that occured were; the destruction of democratic values in society, the weakening of citizenship and community values, the deteriorating values of tolerance, the waning values of honesty, the politeness and the sense of mutual help, the weakening of family values, the rampant practices of corruption, collusion, and nepotism in government system, the flaw of system and economy, and the violation of national values .

The existence of religions in Indonesia is indeed protected by the 1945 Constitution as a constitutional basis, as stated in article 29, p. 1. The State is based on the one and only God, 2. The state guarantees each and every citizen the freedom of worship in accordance with his religion and belief. Pancasila, the official foundation of Indonesia, with the slogan "Unity in Diversity" which simply means unity in diversity and dversity in unity, it will encourage tolerance for every religious community in Indonesia.

Indonesia is neither a religion (theocracy) (Sukardja, 1995, p. 90 \& KBBI, 1989, p. 932), nor a secular state (Smith, 1985, p. 13), but Indonesia's value is right in between, that is Pancasila state with all its values. In Indonesia, the country is not identical with certain religion, but it does not separate itself from religion in its affairs. The state is responsible for the existence of religion, religious life, and inter religion harmony.

\section{Tolerance}

According to Nurcholish Madjid (1999, p. 5) tolerance is a matter of values and the obligation to carry out that values. If tolerance results in a "good" interaction between different groups, then it must be understood as "wisdom" or "benefit" from the implementation of a righteous value. 
The wisdom or benefit is the secondary value, while the primary is the righteous value itself. As primary value, tolerance must be implemented and manifested in society, even if for certain groups - for themselves - the implementation of tolerance consequently may not come with something "nice".

The problem of interfaith tolerance is oftenly caused by the excessive fanaticism of religion which raises radical attitudes. Therefore, a concrete efforts to build interfaith tolerance in society needs to be done as part of a sustainable social process (Zuhari and Zada, 2004, p. 56).

If only the community already had values of togetherness, tolerance, peace of mind, and respect of diversity from the beginning, then these values were the manifestations and reflected in their daily behavior since those are formed in their personality. If our young generation has those values, then the future life can be predicted to be relatively peaceful and full of respect among community.

Masrurah, et al (2017, p. 129) decodes manifestation as "Tolerance manifestation is a kind of someone's attitude that can accept someone else, so that, religious tolerance is a kind of someone's attitude to accept and respect the presence of other person with different religion although he/she does not agree with other's faith. Another word of tolerance is tasamuh".

The concept of tolerance itself is the attitude of recognizing and respecting the beliefs of others without the need for approval. Arabic translates tolerance with the word "tasamuh", which means as mutual permission; mutual convenience. Thus, tolerance can be interpreted as giving freedom to the minority groups to adhere and express their political and religious views, giving special rights as obtained by the majority groups (Asryi, 2002, p. 22).

Tolerance means to allow, leaving what in principle does not need to happen. So tolerance has a concession meaning, means a gift which 
solely based on mercy and kindness, not based on rights. It is clear that tolerance occurs and applies because there are differences in principles and in respecting the differences or principles of others should be without sacrificing someone's principles. Tolerance in inter religion interaction is not tolerance in religious matters, but rather the manifestation of the interfaith attitude and interaction in the society or general matter (Asryi, 2002, p. 13).

\section{Multicultural}

Multiculturalism among intellectuals is considered as a policy to achieve a society order in which citizens who come from other religions, tribes, customs, or cultures can live together and mingle in daily life in peace and prosperity without sacrificing their unique characters (Watson, 2004, p. 15).

In connection with the awareness of multiculturalism as a reality of the community, it is necessary to uphold tolerance, because it will build a new awareness that cooperation in diversity is an absolute needs that cannot be abandoned (Zamroni, 2013, p. 58)

In line with that, Musa Asyarie (2004, p. 1) argues that multicultural education is a process of growing respects, sincerity, and tolerance of the diversity of cultures that existed in the midst of a pluralistic society. By multicultural education, according to Musa Asyarie, it is hoped that the nation's resilience and mental flexibility can overcome the social conflicts.

Therefore, multicultural education in Indonesia needs to use a combination of existing models, as proposed by Gorski, multicultural education and tolerance can cover three types of transformation, namely: (1) self transformation; (2) school transformation and teaching and learning processes, and (3) community transformation (Mahfud, 2009, p. 15). 


\section{Pluralism}

Musa Asyarie stressed that the problem (religious pluralism) is no longer a matter of Islamic doctrine, because doctrinally, Islam has taught about plurality of religions, but the internal problems of Muslims themselves, that is the problem of understanding Muslims towards the source of their own doctrine. Without the willingness of Muslims in accepting the existence of religious plurality, it will create problem and internal and external conflict that can lead to violence, which actually seem to conflict the principle of the meaning of Islam itself, that is rahmatan lil'alamin, a mercy for the universe (Asy'arie, 1999, p. 142-143).

Indeed, if it is realized that the plurality of culture, tradition and religion are the necessities of life, as every person or community must have differences and similarities. On the other hand, the plurality of cultures, traditions and religions are another wealth for the Indonesian people. But if it is not understood with tolerance and mutual respect of the plurality of cultures, religions or traditions, it tends to trigger violence of SARA (ethnicity, religion, ancestry, and group of people) (Baidhawy \& Jinan, 2003, p. 71).

If being examined more deeply, in fact, plurality is the will of the Creator (sunatullah) so that this life can be in balance. Actually, the existence of plurality in society makes people live in dynamic, colorful, exciting, and interdependent. In other words, plurality enriches the life and becomes the essence of people's lives so that the actions to reject or eliminate the existence of plurality is basically rejecting the essence of life itself (Asy'arie, 2002, p. 110).

\section{ISLAM AND INTERFAITH HARMONY}

Al-Quran is the holy book of Islam which is the revelation of Allah which was revealed to the Prophet Muhammad SAW. carried by the Gabriel with its lafadz (verses) and righteous meaning as proof of 
its authenticity, which became a guidance for humans in their lives to actualize their salvation and peace the world and hereafter (Khalaf, 1996, p. 22).

Peace is one of the principles instilled by Islam in the souls of the Muslims. Peace has become part of the existence of the belief (aqeedah). Since its emergence, Islam has called for the word peace that resonates throughout the world. It invites human into peace. Besides, it also formulates the righteous ways so that humans can achieve it. Islam loves and sanctifies life, and invites human to love it. With love for life, Islam removes the excessive fear in human life and arranges the best way for them to live and achieve their goals, that is the progress and development under the auspices of security and peace (Sabiq , 2013, p. 397).

Since da'wah (Islamic preaching) in Islam is an activity of amar ma'ruf nahi mungkar, it does not always revolve around religious issues such as islamic lectures or religious activities. There are, at least, three understandable patterns regarding da'wah. Da'wah is as a form of communication, because communication is an informative activity, so that people can understand and know the persuasive activities, that is, people are willing to accept a belief, performing the belief or activity, etc. Both (da'wah and communication) are integral parts that cannot be separated (Hayati, 2017, p. 179).

The word Islam itself, which is the name of this religion, derived from the word salam which means peace, because salam and Islam melt in one source and the goal is to provide peace and security. One of the names (Allah SWT.), Owner of this religion, is al-Sal $\square m$ (The Peace Giver), because $\mathrm{He}$ is the one Who gives comfort to all human beings with His principles, consents, and methods (Sabiq, 2013, p. 397-398).

Etymologically, Islam is derived from the word salam which means peace. In Islam, the concept of love and peace is very central, so that a number of verses and hadiths are found which explain about it, such as 
"who spend (in the cause of Allah) during ease and hardship and who restrain anger and who pardon the people, and Allah loves the doers of good," (Surah Ali Imran [3] verse 134).

Peace that emerges from the inner peace arises as a product of honesty, sincerity, generosity and tolerance that is emphasized by Islam. Besides, Islam teaches its followers to control their anger and forgive those who have made mistakes to them. The Prophet said,

"Narrated by Ibrahim bin Sa'id al-Jauhari Abu Usamah, narrated by Buraid bin Abdullah from Abi Burdah from Abi Musa said: "Rasulullah PBUH was being asked about who is the best Muslim? Rasulullah said: Muslims who are able to make other Muslims feel safe from their words and hands," (Al-Tirmidhi, t. 44).

Islam emphasizes social harmony, by ordering its follower to reflect the peace and compassion in their social interactions. Humans have the right to life, property rights, justice rights, honor rights, rights of religious freedom, and the right of morality. These rights are the rights given by God which must be implemented under any circumstances. Islam emphasizes justice and equal treatment for all, including to the enemy "do not let your hatred to a group makes you unfair, be fair because it is closer to taqwa."

The best person in the sight of Allah and the closest to Him is the one who first saying $s a \square m$ to his Muslim fellows. Spreading $s a l \square m$ (peace) to the world is part of faith. Allah has made the utterance of respect among fellow Muslims as a religion of peace. So, their identity is a peaceful and loving society (Sabiq, 2013, p. 398).

Islam comes as a religion that carries a mission of peace and forbids human to do injustice. Peace is salvation for individuals, society and even for all human. There is the needs to be secure to eliminate the sense of hostility, because hostility will always interfere human with the safety of their souls. 
Viewed from the historical side of the construction process of Medina by the Prophet Muhammad, facts were discovered about the recognition and appreciation of the value of pluralism and tolerance (Muliadi, 2012, p. 65). 62, 136, 115 and 256, al-Kafirun: verse 6, alShura verse 13, al-Nisa' verse 131. From these verses, it is implied that Muslims should strongly realize that; pluralism in religion is the will of God, therefore, it is forbidden to impose beliefs to others, because forced beliefs are only the outer aspect, while the spiritual aspects are untouched, so it will create hypocrite human beings. Rasulullah has also conveyed through his hadith narrated by Ibn 'Abbas, he said, "being asked to the Messenger of Allah, "Which religion is the most beloved by Allah?" then he said: "Al Hanifiyyah As-Samhah (the righteous and tolerant)."

It is concluded that the verses which talk about peace, tolerance, forgiveness and patience, generally revealed before the Prophet emigrated (hijrah) or included in the Makiyah period. While the sword verse (commonly called as the verse of qital or saif), is madaniyah (Qardhawi, 2010, p. 130).

As an evidence through Rasulullah that Islam the religion of peace is when Hajar al-Aswad shifted from its place due to the heavy rain, then the Arab people argued about who has the right to put al-Hajar Aswad to its original place. Finally, they agreed that Muhammad should be the peacemaker of this problem. After the advent of Islam, the great event that further underlies the revival of Islamic politic is the role of the Prophet Muhammad in reconciling two large groups of Madinah people, the Aus and Khajraz tribes who are constantly in hostility and attacked each other. By the presence of the Prophet to Medina, the two tribes were in peace and became the power of the Muslim society that time (Nurdin, 2010, p. 140-141).

As stated by Azyumardi Aza, religion has two major roles: first, religion teaches us how to perform rituals. In Islam, for example, how 
someone performs prayer, fasting, zakat (alms), etc. Secondly, religion teaches peace and tolerance. This second role is the one which can contribute to the prevention of war and conflict (Azra, 2005).

Regarding religious conflicts, Abdul Mustaqim mentions that, at least, there are five reasons stated in the Qur'an. They are: First, excessive fanaticism makes people to see their community as the right one (Surah al-Mu'minun [23] verse 53). Second, extreme religious practice triggers a person to be intolerant of other religions and anti-reconciliation with those who are theologically different (Surah al-Nisa '[04] verse 171). Third, disrespecting and giving negative label (stereotipe) between one group to another group (Surah al-Hujurat [49] verse 11). Fourth, being suspicious and distrustful to the other groups (Surah al-Hujurat [49] verse 12). Fifth, the mutual ruthlessnes triggers religious conflict (Surah al-Mumtahanah [60] verse 8) (Mustaqim, 2011, p. 11-12), Thus, creates radicalism.

In the "community" area which is formed in the midst of human life may not deny the essence of humanity. Someone who lives in a society, his essence of humanity must be guaranteed and recognized. Likewise, a person who lives in a country, his humanity values must not be neutered. One of the essence of humanity is the recognition of diversity.

The discussions about the issue of religious tolerance in this country, especially with the frequent occurrence of conflict in the community which allegedly triggered by the elements of SARA (ethnicity, religion, ancestry, and group of people), are so rampant. The religious tolerance issues are growing, if we take a closer look, because of the importance of developing tolerance and respect in inter religion (Nadroh, 1999, p. 109120).

It becomes a major challenge for Muslims today to explore the roots of the plurality of tradition in the interpretation and implementation of the holy book. The way is that, to develop a culture of tolerance, the relations between the madzhab (islamic view), organizations, and associations in a 
dialogical and peaceful world of Islam (ikhtilaf al ummahti rahmah). Islam is one, but the manifestations are culturally diverse. Without restoring the principle of coexistence (peaceful coexistence), Muslims will be trapped in the thoughts of the Khawarijs who claim that the truth is only theirs. All people and groups who have different theological perspectives are misguided and their blood (killing them) is lawful. If such violent culture is developed continuously, we will not be able to revive the spirit of prophethood like the Madani society under the governance of the Prophet Muhammad. The triumphal of Islamic civilization can be revived if the people are able to make substantial differences as social or capital assets. Islamic civilization reaches its peak when harmony and mutual respect on differences in interpretation (madzhab) are achieved. Freedom in madzab (islamic view), allows the possibility of constructive dialogue on the basis of morals, mutual trust, and mutual respect. On the contrary, the decline of Islamic civilization occurs when there is chaos, slander, absolutizing the truths among the people religious practices. Imposition, hegemony and tyranny which oppress different groups results in the weakening of people's solidarity and the decline of civilization (Mufid, 2013, p. 15).

Muhammad Ali argues that moderate Islamic ideology can be grown through a pluralist-multicultural education model. According to him, pluralist-multicultural in religious education is important for the students' view to be able to respect differences, respect people sincerely, communicative, open minded, and less suspicious, in addition to increase the faith and piety. Pluralist-multicultural education is not teaching the students to practice the religion arbitrarily, without any responsibility and sincerity, but instead to be religious, without losing their respective religious identities. The face of religion presented by pluralist education -multicultural is a moderate and friendly religion (Ali, 2003, p. 102).

In this modern era, multicultural education is important to overcome various problems caused by the advancement of information of 
technology. For example, the rise of hoax news about the issue of SARA, which drives the radical ideologies arises, needs to be addressed since its early stage arises. Various information is accessible easily and quickly to the public so that the awareness of diversity of ethnicity, culture and religion facilitated by proper education system is needed.

Modern life and the advancements of technology have positive and negative impacts, so it is necessary to shape ourselves to be able to overcome it. This is in line with Rahmad et al (2017, p. 797), they stated that,

"On the other hand, all circles have made the Internet as a daily necessity that cannot be separated. All information can be accessed freely through the Internet. However, for most modern society, the internet is more likely to be used for information and entertainment only. Not even a few who abuse for various purposes. For a Muslim, when he sees something that is not good then as much as possible he tries to prevent or improve it in accordance with the level of ability."

Thus, the existence of moderate Islamic education is important in Indonesian context, amidst the rise of various radical ideologies that have entered Indonesia through the transnational network. At the Limited Meeting in June 5, 2015 at Bogor Palace, President Joko Widodo invited the Indonesian Ulema Council, Islamic organizations and, chancellors of some of Islamic State University in Indonesia, to initiate moderate Islamic education in Indonesia. On that occasion, the President emphasized that Indonesian Islam is moderate Islam that always harmoniously coexists with other religions, and this is the reflection of Islam which not only creates a good image of Indonesia as a nation of plurality, but also rahmah lil al-'âlamîn (nasional.news.viva.co.id).

\section{THE POTENCY OF ISLAMIC FORUM}

Islamic Forum (Majelis taklim) derived from Arabic which consisted of two words namely majlis means "place" and taklim which means "teaching". So etymologically, majelis taklim means "a place of 
teaching and learning". Terminologically, majelis taklim is a non-formal educational institution taught by ustadz/ustadzah (islamic teacher), has members to learn Islamic values and other beneficial activities in specified place. The Ministry of Religion Affairs defines majlis taklim as an Islamic educational institution that has periodical or regularly learning schedule, but not in every day basis schedule as in school, the members are voluntary, it is not a compulsory since it is considered as their spiritual needs (Ministry of Religion Affairs, 2008, p. 3).

Majelis Taklim has many functions, for instance, as the center for value of peace, the center of agent of change to be a better Muslims, the center for community development, the center for communication and information, the center of cadre and social control agent (Astari, 2014, p. 56). These functions must be carried out in the majelis taklim in developing advanced, independent and civilized society. To share the truth of Islam and educate the people so that they can act wisely. It can be called as Islamization, a way to improve and develop the betterment of community (Poston, 1992, p. 3).

Majelis ta'lim is an institution that organizes the place for the implementation of Islamic teaching and learning (Asrohah, 1999, p. 50). While the definition of Majelis taklim according to Harizah Hamid is a forum or organization that promotes religious activities, that is Islam (Hamid, 1991, p. 14). Another opinion expressed by Hasbullah, he said that: Majelis taklim is a place for teaching and learning islam (Hasbullah, 1995, p. 202). Another opinion that strengthens the three opinions above is Ramayulis's statement that Majelis taklim is a non-formal educational institution to provide Islamic teaching (Ramayulis, 1994, p. 142). Thus, Majelis ta'lim is a non-formal educational institution and is one of the places to carry out Islamic religious activities such as teaching the values of Islam through lectures (Ramayulis, 1994, p. 45). Thereore, Majelis taklim incarnates as a forum for the realization of multicultural and tolerance 
education that covers self transformation and transformation of society

Finally, Majelis ta'lim can be seen as a solution of planting the seeds of democracy, tolerance and multicultural for the emergence of inter religion harmony in Indonesia. Majelis ta'lim is also a great potential for this country to create a harmonious country, to be free from radicalism, and to be able to reduce SARA conflicts, which often arise from the institutionalization of a community.

\section{CONCLUSION}

The process of growing multiculturalism values and inter religion tolerance among community in Indonesia can be done by lecturing/ recitation in Majelis ta'lim (Islamic forum) which are spread in mosques, houses, meeting halls and so forth. Inter religion tolerance can be developed through; (1) preachers, islamic leaders and activists are hoped to insert some values of multiculturalism and inter religion tolerance in their lectures in mosques or forum. (2) Lcturers, preachers, and islam activists are hoped to completely understand the multicultural values and inter religion tolerance since the lack of understanding of those values might affect the integration of their lectures. (3) The planting of multicultural values and inter religion tolerance must be communicated to the public to shape the individuals who truly have democratic attitudes, equality of gender, justice, tolerance, human rights, and unity. (4) A multicultural and inter religion tolerance values in religious lectures can be developed as a way of transferring the knowledge related to multiculturalism and interfaith tolerance as there are many sources which has Islamic values. (5) Indonesians and the Javanese, especially Muslims and islamic activists, should be the example for the society in spreading these values through Majelis ta'lim. Hopefully our country can be a peaceful and prosperous country. 


\section{REFERENCES}

Al Makin. 2017. Homogenizing Indonesian Islam: Persecution of the Shia Group in Yogyakarta, Studia Islamika, Indonesian Journal for Islamic Studies, Vol. 24, No. 1, 2017.

Ali, Muhammad. 2003. Teologi Pluralis-Multikultural: Menghargai Kemajemukan, Menjalin Kebersamaan. Jakarta: Kompas.

Arif, Dikdik. Baehaqi.Kompetensi Kewarganegaraan untuk Pengembangan Masyarakat multikultural Indonesia.Jurnal Pendidikan Kewarganegaraan, Vol. 2, No. 1, 2008.

Asrohah.Hanun. 1999. Sejarah Pendidikan Islam.Jakarta: Logos.

Asryi, Zuly. Toleransi Islam terhadap Agama Lain, Dalam Al-Fikra Jurnal Ilmiah (Yogyakarta: UIN SUKA Press, 2002).

Astari, Puji. Mengembalikan Fungsi Masjid Sebagai Pusat Peradaban Masyarakat.Jurnal Ilmu Dakwah dan Pengembangan Komunitas. Vol. 9, No. 1, Januari 2014.

Asy'arie, Musa. 2005. NKRI, Budaya Politik dan Pendidikan. Yogyakarta: LESFI.

, Musa. 1999. Filsafat Islam Tentang Kebudayaan. Yogyakarta: LESFI. , Musa. 2002. Dialektika Agama untuk Pembebasan Spiritual.Yogyakarta: LESFI.

Azra, Azyumardi. 2005. Teaching Tolerance through Education in Indonesia, Reflections on the Keynote Address and Symposium Theme of International Symposium on Educating for a Culture of Peace through Values, Virtues, and Spirituality of Diverse Cultures, Faiths, and Civilizations, MultiFaith Centre. Griffith University, 10-13 August 2005.

Badan Litbang Puskur. 2010. Badan pelatihan penguatan metodologi pembelajaran berdasarkan nilai-nilai budaya untuk membentuk daya saing karakter bangsa. Bandung: P4TK.

Baidhawy, Zakiyuddin.The Problem Of Multiculturalism: Radicalism Mainstreaming through Religious Preaching in Surakarta. Journal of 
Indonesian Islam, Vol. 4, No 2, 2010.

Blum, Lawrence A. 2001. Antirasisme, Multikulturalisme, dan Komunitas antar Ras: Tiga Nilai yang Bersifat Mendidik bagi Sebuah Masyarakat Multikultural, dalam Larry May, Etika Terapan I Sebuah Pendekatan Multikultural, edisi terj. Sinta Carolina, dkk. Jogjakarta: Tiara Wacana.

Departemen Pendidikan dan Kebudayaan. 1989. Kamus Besar Bahasa Indonesia. Jakarta: Balai Pustaka.

Geertz, Clifford. 2014. Agama Jawa: Abangan, Santri, Priyayi Dalam Kebudayaan Jawa. Depok: Komunitas Bambu.

H.A.R. Tilaar. 2004. Multikulturalisme: Tantangan-tantangan Global Masa Depan dalam Transformasi Pendidikan Nasional. Jakarta: Grasindo. Hamid, Harizah. 1991.Majelis Taklim. Jakarta: Bulan Bintang. Haryatmoko. 2003.Etika Politik dan Kekuasaan.Jakarta: Kompas. Hasbullah. 1995. Sejarah Pendidikan Islam di Indonesia. Jakarta: Rajawali. Hayati, Umi. Nilai-Nilai Dakwah: Aktivitas Ibadah dan Perilaku Sosial. INJECT: Interdisciplinary Journal of Communication.Vol. 2, No.2, Desember 2017.

Hernandez. Hilda. 1989. Multicultural Education: A Teacher Guide to Linking Context, Process and Content. New Jersey \& Ohio: Prentice Hall. Jadidah, Amatul. Paradigma Pendidikan Alternatif: Majelis Taklim Sebagai Wadah Pendidikan Masyarakat. LP3M IAI Al-Qolam, Jurnal Pusaka, Vol. 7, 2016.

Banks, James A \& Banks. Cherry.A.Mc Gee. Handbook of Research on Multicultural Education. (New York MacMillan, 2001), Eds. , James A. 2002. An Introduction To Multicultural Education. Boston: Allynand Bacon.

, James, A. 2007. Educating Citizens In A Multicultural Society. New York:Teachers College Columbia University. , James A. 1984. Teaching Strategies For Ethnic Studies. Newton: Allyn and Bacon. 
, James A. Diversity, Group Identity, and Citizenship Education in a Global Age, (Educational Researcher: An Official Journal of The American Educational Research Association, Vol. 37, No. 3, April 2008.

Julaiha, Siti. Penanaman Multikulturalisme dalam Pendidikan Islam, (Jurnal Dinamika Ilmu, Vol.24, No. 1, Juni 2014).

Khalaf.Abd.Wahab. 1996. Ilmu U $\square l$ Al-Figh. trans. Noer Iskandar alBarsany dkk.Jakarta: PT. Raja Grafindo Persada.

Kymlicka, Will. 1999. Mitsunderstanding Nationalism, dalam Theorizing Nationalism, ed. R. Beiner. Albany: State University of New York.

M. Jandra dalam Baidhawy Zakiyuddin \& Jinan Mutohharun. 2003. Agama dan Pluralitas Budaya Lokal. Surakarta: UNM.

Madjid, Nurcholish. 1999. Cita-Cita Politik Islam Era Reformasi. Jakarta: Paramadina.

, Nurcholish. Masyarakat Madani dan Investasi Demokrasi: Tantangan dan Kemungkinan. Republika, 10 Agustus 1999

Mahfud, Choirul. 2009. Pendidikan Multikultural. Yogyakarta: Pustaka Pelajar.

Masruhah, Ummahatul \& Triyani Ely Mei, Sabrina Aulia, Prihastuty Rahmawati. Religious Tolerance to Adherents of Islam and Hinduism in Kongkong Village. The International Journal of Indian Psychology. vol.4, issue 4, Juli-September 2017.

Miswari Zuhari dan Khamami Zada. 2004. Islam Melawan Terorisme. Ciputat: LSIP.

Moedjono, Iman. 1997. Peran Pendidikan Islam dalam Mewujudkan Kerukunan Antar Umat Beragama", dalam Pendidikan Islam dalam Peradaban Industrial.Yogyakarta: Aditya Media.

Mufid, Ahmad Syafi'i. Radikalisme dan Terorisme Agama, Sebab dan Upaya Pencegahan. Jurnal Multikultural \& Multireligius Vol. 12, No. 1.2013. 
Muliadi,Erlan. 2012. Urgensi Pembelajaran Pendidikan Agama Islam Berbasis Multikultural di Sekolah. Jurnal Pendidikan Islam, Vol. I No.1.

Mulkhan, Abdul Munir. 2005. Kesalehan Multikultural: Ber-Islam Secara Autentik-Kontekstual di Aras Peradaban Global, Pusat Studi Agama dan Peradaban (PSAP) Muhammadiyah; Cetakan: Pertama

Mustaqim, Abdul. 2011. Konflik Teologis dan Kekerasan Agama Perspektif Tafsir al-Quran, Makalah Pengantar Mata Kuliah Studi Quran: Teori dan Metodologi, Program Pasca Sarjana UIN Sunan Kalijaga Yogyakarta.

Mustofa, Muhamad Arif. Majelis Taklim Sebagai Alternatif Pusat Pendidikan Islam (Studi Kasus pada Majelis Taklim Se Kecamatan Natar Lampung Selatan), Fokus ; Jurnal Kajian Keislaman dan Kemasyarakatan, Vol. 1 No. 01, 2016

Nadroh, Siti. 1999. Wacana Keagamaan dan Pohtik Nurcho\&s Madfid. Jakarta: Raja Grafmdo Persada.

Nurdin, Ridwan. 2010. Fiqh Muamalah (Sejarah Hukum dan Perkembangannya). Aceh: PeNA.

Nuryatno, Agus. Islamic Education in a Pluralistic Society, Al Jamiah Journal of Islamic Studies, Vol 49, No 2, 2011.

Poston, Larry. 1992. Islamic Dakwah in the West: Muslim Missionary Activity and Dinamic of Conversion. New York: Oxford University Press.

Qardhawi, Yusuf. 2010. Fiqh al-Jihad, alih bahasa Irfan Maulana Hakim dkk., (Cet. I, Bandung: Mizan, 2010

Ramayulis. 1994. Ilmu Pendidikan Islam. Jakarta: Kalam Mulia.

Rufaida, Hasna. Menumbuhkan Sikap Multikultural Melalui Penanaman Nilai-nilai Multikultural dalam Pembelajaran IPS. Journal SOSIO DIDAKTIKA: Social Science Education Journal, 4 (1), 2017).

Sabiq, Sayyid. 2013. Figih sunah 5, Terj.Abu Syaugina dan Abu Aulia Rahma.Jakarta: Tinta Abadi Gemilang.

Sapendi .2015. Penanaman Nilai-nilai Multikultural Dalam Mata Pelajaran Agama Islam di sekolah, (Raheem, Jurnal Studi Gender dan Anak, 
Vol. 2, No. 1.

Saputra, Rahmat, NazimAzzyati Mohd, Islamiyah Ummi Habibatul. 2017. Dakwah Strategy "Persaudaraan ProfessionalMuslim (PPM) Aswaja" Through the Internet. International Journal of Academic Research in Business and Social Sciences.Vol. 7, No. 6.

Sarbini, Ahmad. 2010. Penanaman Nilai Keislaman Melalui Majlis Taklim, Jurnal Ilmu Dakwah, Vol. 5 No. 16.

Setiawati, Nur. Majelis Taklim dan Tantangan Pengembangan Dakwah, (Jurnal Dakwah Tabligh, Vol. 13, No. 1, Juni 2012).

Sikumbang, Ahmad Tamrin. Persepsi Masysrakat Tentang Materi Ceramah Da'i di Kota Medan, (Studi Pada Anggota Jamaah Majelis Taklim Al-Ittihad), Jurnal Analytica Islamica, Vol. 1, No. 1.2012.

Smith, Donald Eugene. 1985. Agama ditengah Sekulerisasi Politik.terj. Azyumardi Azra. Jakarta: Pustaka Panjimas.

Sugiyarto,Wakhid. , 2009. Ikatan Jama'ah Ahlul Bait Indonesia (IJABI) di Jawa Barat, dalam Kasus-Kasus Aliran/Paham Keagamaan Aktual di Indonesia, ed. Ahmad Syafi'i Mufid Jakarta: Puslitbang Keagamaan DEPAG RI.

Sukardja, Ahmad. 1995. Piagam Madinah dan Undang-Undang Dasar 1945; Kajian Perbandingan Tentang Dasar Hidup Bersama Dalam Masyarakat yang Majemuk.Jakarta: UI Press.

Suparlan, Parsudi. Menuju Masyarakat Indonesia yang Multikultural, (Simposium Internasional, Jurnal Antropology Indonesia, 69), Denpasar Bali ke-3, 16-21 Juli 2002.

Syahid, Bakri. 1979. Al-Huda: Tafsir Qur'an Basa Jawi .Yogyakarya: Bagus Arafah.

Syammsudin, Din. Paper diseminarkan dalam Multikultural Internasional Wolrd Culture Forum (WCF) di Nusa Dua, Bali, Rabu (12 Oktober 2016).

Tim dan Penulis Departemen Agama, Pedoman Pengelolaan Majlis Taklim. (Jakarta: Dipendis Ditjen PAI Departemen Agama RI, 2008). 
Watson, B., Multikulturalism: Its Strength and Weaknesses. Jurnal Pendidikan Ilmu Sosial, (23), 2004.

Yunus, Firdaus M. Konflik Agama di Indonesia, Problem dan Solusi Pemecahannya, Substantia, Vol. 16 No. 2, Okotber 2014.

Zamroni. 2007. Pendidikan dan Demokrasi dalam Transisi (Prakondisi Menuju Era Globalisasi). Jakarta: PSAP. , 2013. Pendidikan demokrasi pada masyarakat multikultural. Yogyakarta: Gavin Kalam Utama.

\section{Sumber Internet:}

Anita Lie. Mengembangkan Model Pembelajaran Multikultural http://www. kompas.com/kompas-cetak/diakses 30 September 2018.

http://nasional.news.viva.co.id/news/read/634595-jokowi-inginpertahankan-pendidikan-islam-moderat"Jokowi Ingin Pertahankan Pendidikan Islam Moderat" http://www.pikiran-rakyat.com/pendidikan/2015/06/05/329989/

jokowi-ingin-bangun-universitas-islam-moderat "Jokowi Ingin Bangun Universitas Islam Moderat"

https://hukamnas.com/contoh-konflik-antar-agama.

https://www.republika.co.id/Pembakaran Masjid Diduga karena Muhammadiyah Dituduh Wahabi.

Musa Asy'arie. Pendidikan Multikultural dan Konflik Bangsa (www.kompas. co.id. 2004).

sangpencerah.id. Kelompok Intoleran Berhasil Bubarkan Tahfidzul Quran Muhammadiyah. 